\title{
Harmonisation of avoidance rules in European Union insolvencies: the critical elements in formulating a scheme
}

\author{
ANDREW KEAY* \\ University of Leeds and Deakin University
}

\begin{abstract}
Only the harmonisation of laws is seen as being able to solve legal uncertainty resulting from legal diversity, but, notwithstanding the advent of the EC Regulation on Insolvency Proceedings, thus far there is no real harmonisation of insolvency laws in the EU. There are indications that the European Commission (EC) has been considering the formulation of a scheme for the harmonisation of the rules that apply in insolvency proceedings to permit the avoidance of transactions entered into prior to the commencement of insolvency proceedings. On this basis this article identifies and analyses those factors that will need to be considered and addressed in the formulation of any harmonised scheme, as well as ascertaining the problems that these factors may cause in the construction of such a scheme. This is a critical issue, for it is all well and good to say that there should be harmonisation, but how that is done, what must be taken into account and what is included in any harmonised scheme is another matter and requires careful thought and consultation.
\end{abstract}

Keywords: avoidance rules; harmonisation; insolvency proceedings; European Union

\section{Introduction}

$\mathrm{H}$ armonisation in law refers to efforts to change the laws of two or more countries to be more substantively similar to each other. ${ }^{1}$ The UN Committee on International Trade Law (UNCITRAL) has defined harmonisation as: 'the process through which domestic laws may be modified to enhance predictability in cross-border commercial transactions'. ${ }^{2}$ In the European Union (EU) context harmonisation has been seen as an instrument that is complementary to the general articles in the Treaty of Rome (the Treaty) when free movement of capital, goods, persons and services has not been achieved. ${ }^{3}$

\footnotetext{
* Professor of Corporate and Commercial Law, Centre for Business Law and Practice, School of Law, University of Leeds; Professorial Research Fellow, Deakin Law School, Deakin University, Melbourne; and Barrister, Kings Chambers and 9 Stone Buildings.

1 Draft Common Frame of Reference Outline Edition 2009, Annex (Definitions) 555 and referred to in American Law Institute and the International Insolvency Institute, 'Transnational Insolvency: Global Principles for Co-operation in International Insolvency Cases' (American Law Institute, Philadelphia 2012), fn 209.

2 UNCITRAL, 'FAQ - Origin, Mandate and Composition of UNCITRAL' and quoted in S Block-Lieb and R Halliday, 'Harmonisation and Modernization in UNCITRAL's Legislative Guide on Insolvency Law' (2007) 42 Texas International Law Journal 475, 493.

3 P Slot, 'Harmonisation' (1996) 21 European Law Review 378, 379.
} 
Harmonisation should be employed to realise market integration. ${ }^{4}$ Only the harmonisation of laws is seen as being able to solve legal uncertainty resulting from legal diversity. ${ }^{5}$ It is provided for in Article 3(h) of the Treaty as one of the mechanisms that is to be used in order to attain the aims of the Treaty, ${ }^{6}$ so that it will be employed as a device to the degree that it is necessary for the appropriate functioning of the Common Market. It is deemed necessary because of economic pressures in the EU relating to the Common Market and facilitation of trade. ${ }^{7}$ Attempts to harmonise civil law in earnest can be traced back to the late $1980 \mathrm{~s},{ }^{8}$ when harmonisation was employed in addressing several private law matters in the Single European Act (in 1987).?

Thus far harmonisation in insolvency law has only occurred to a very limited extent. Harmonisation commenced with the enactment of the European Regulation on Insolvency Proceedings (the Regulation) which became law across the EU, with the exception of Denmark, on 31 May 2002. It was felt that the Regulation was needed because national legal systems could not achieve the proper functioning of the internal market. ${ }^{10}$ The goal of the Regulation was to provide for a universalist insolvency model, ${ }^{11}$ founded on one law applying to an insolvency proceeding, and for that law to apply to all matters that related to that proceeding across the breadth of the EU. This was designed to improve the effectiveness and efficiency of insolvency proceedings having cross-border effects. ${ }^{12}$ Recital 4 of the Regulation ${ }^{13}$ provided that it was necessary to enable the proper functioning of the EU's internal market to prevent people having incentives to transfer assets or judicial proceedings between member states and thereby obtaining a more favourable legal position. The Regulation's objective was to produce a marked reduction in costs incurred in the administration of any insolvency. The Regulation provided clear guidelines that ensured stability and consistency in relation to areas of jurisdiction, applicable law and the recognition and enforcement of judgments. ${ }^{14}$ The Regulation has been reviewed and on 26 June $2017 \mathrm{a}$ recast version of the Regulation (EIR) came into force. The EIR very much follows in the tradition of the original Regulation. References to recitals and articles in the EIR in this article are to this later version.

4 Ibid 382.

5 M Haentjens, 'Harmonisation of Securities Law: Custody and Transfer of Securities in European Private Law' unpublished PhD thesis submitted to the University of Amsterdam, 2007, 240.

6 Slot (n 3) 378.

7 L Del Duca, 'Developing Global Transnational Harmonisation Procedures for the Twenty-First Century: The Accelerating Pace of Common and Civil Law Convergence' (2007) 42 Texas International Law Journal 625, 650.

8 H Schulte-Nolke, 'Arbeiten an einem Europaischen Privatrecht - Fakten und populare Irrtumer' (2009) 62 Neue Juristische Wochenschrift 2162, 2162, and referred to in B Zeller, 'Anatomy of EU Contract Harmonisation: Where Do We Stand?' (2015) 21 International Trade Law and Regulation 41, 41.

9 W Van Geren, 'Harmonisation of Private Law: Do We Need it?' (2004) 41 Common Market Law Review 505, 505.

10 Council Regulation on Insolvency Regulations (EC) (1346/2000), 29 May 2000, recital 5.

11 Although Tung referred to the Regulation as providing for a territorialist scheme with universalist pretensions: F Tung, 'Is International Bankruptcy Possible?' (2001) 23 Michigan Journal of International Law 31, 77.

12 Council Regulation on Insolvency Regulations (n 10), recital 8.

13 Recital 5 of the recast version of the EIR.

14 Seagon v Deko Marty Belgium NV (Case C-339/07) [2009] BCC 347, [59]. 
While the EIR goes some way towards harmonising the private international law rules as far as insolvency proceedings are concerned in the member states of the EU, ${ }^{15}$ it clearly did not purport to seek to harmonise substantive insolvency law, save in a very limited way. The EIR ensures that decisions on cross-border insolvencies are recognised across the EU and designates both the courts that will have the power to open insolvency proceedings and what law will be applied to the insolvency proceedings.

During the first decade of this century the issue of insolvency law harmonisation was avoided, ${ }^{16}$ yet in more recent times the possibility of harmonisation of substantive insolvency law or, at least, elements of it has been seriously considered. In 2010, following a request from the European Parliament, INSOL Europe ${ }^{17}$ prepared a report which examined the need for and the feasibility of harmonisation of European insolvency law. The report concluded that several topics were apt for harmonisation and that harmonisation in relation to these topics was desirable and achievable. ${ }^{18}$ One of these topics dealt with the avoidance rules applied to insolvencies. Such rules enable transactions or elements of transactions made prior to a debtor entering insolvency proceedings to be avoided (antecedent transactions). These actions are brought, usually, by a person appointed to administer the insolvent estate of a debtor against a third party who has benefited from a transaction entered into with the debtor prior to the opening of insolvency proceedings in relation to the debtor seeking the avoidance of the transaction. ${ }^{19}$ This may then lead to the augmentation of the assets comprised in the insolvent estate and, hence, a greater payment to the general creditors of the debtor.

The publication of the INSOL Europe report precipitated one commentator to state that: 'Insolvency Law has finally become a field of law for which harmonisation at a European level is considered both important and feasible.' 20 This can be linked to the fact that the reform of insolvency law is very much near the top of the EU's policy agenda. It is an important element of the EU's Capital Markets Union project, and the Five Presidents' Report: Completing Europe's Economic and Monetary Union on 22 June $2015^{21}$ lists the area of insolvency law among the most important bottlenecks preventing the integration of capital markets. ${ }^{22}$ Recently the European Central Bank called for the harmonisation of avoidance actions. $^{23}$

15 T Bos, 'The European Insolvency Regulation and the Harmonisation of Private International Law in Europe' (2003) Netherlands International Law Review 31, 33.

16 B Wessels, 'Harmonisation of Insolvency Law in Europe (2011) 8 European Company Law 27, 27.

17 The European Association of Insolvency Practitioners and Scholars.

18 European Parliament, 'Harmonisation of Insolvency Law at EU Level' PE 419.633, Study by INSOL Europe, April 2010, 20: <http://www.europarl.europa.eu/meetdocs/2009_2014/documents/empl/dv/ empl_study_insolvencyproceedings_/empl_study_insolvencyproceedings_en.pdf $>$.

19 As discussed later in the article, others, such as creditors, might be entitled under national legislation of member states to bring avoidance proceedings in some situations.

20 R J de Weijs, 'Harmonisation of European Insolvency Law and the Need to Tackle Two Common Problems: Common Pool and Anticommons' 19 October 2011, $1<$ http://ssrn.com/abstract=1950100>.

21 Available at <https://ec.europa.eu/priorities/publications/five-presidents-report-completing-europeseconomic-and-monetary-union_en>.

22 EC (DG Justice and Consumer Affairs), 'Study on a New Approach to Business Failure and Insolvency' Tender No JUST/2014/JCOO/PR/CIVI/0075, January 2016, 23 <https://www.cak.cz/assets/proadvokaty/mezinarodni-vztahy/insolvency_study_2016_final_en.pdf $>$.

23 Opinion of the European Central Bank, 7 June 2017, para <https://www.bankingsupervision.europa.eu/ecb/legal/pdf/con_2017_22_signed_with_twd.pdf>. 
Following the abovementioned INSOL Europe report, the European Parliament in a Resolution of 15 November $2011^{24}$ said in recitals that there are certain areas of insolvency law where harmonisation is worthwhile and achievable. The Parliament stated that the lack of harmonisation inhibits predictability of the results of court proceedings. $^{25}$ Also a report by the Association for Financial Markets in Europe in February 2016 concluded that convergence of insolvency law and practice provides for significant benefits. ${ }^{26}$ The European Parliament said that even if the creation of a body of substantive insolvency law at EU level is not possible, there are certain areas of insolvency law where harmonisation is worthwhile and achievable. ${ }^{27}$ One of those areas that INSOL Europe and the Parliament felt was ready for harmonisation was the avoidance rules. But, the INSOL report did not endeavour to provide any possible rules that might be applied as far as harmonisation was concerned.

While not mentioned in the INSOL report, another more recent report, which involved a study into substantive insolvency law in the $\mathrm{EU},{ }^{28}$ has found that there are many divergences in the avoidance rules applying across the EU and the provisions of the EIR do not alleviate those or provide a fair resolution of avoidance issues. ${ }^{29}$

There are various shades of harmonisation, but it would seem that what is being envisaged as far as the avoidance rules are concerned is total harmonisation (or exhaustive, hard, maximum or strong harmonisation as it is variously referred to). This is when no lack of adherence to rules is permitted save where safeguard measures are needed. ${ }^{30}$ The topic of this paper is considered in the context of total harmonisation.

Where there is total harmonisation, rules will apply across the EU in all insolvencies. There are indications that this approach might be favoured by the EC, but, having said that, it would not appear to be a straightforward answer to the problem when one considers what the provisions of the law will actually be. There are obstacles that would have to be overcome. Any consideration of a harmonisation process in insolvency, where a multitude of jurisdictions is involved, must involve careful thought being given to how the harmonisation will affect and relate to other issues, both involving insolvency and non-insolvency areas of law. ${ }^{31}$ Certainly, achieving harmonisation will not be an easy task. There will be some hard decisions that the EC will have to make.

The aim of this paper is to identify and analyse those primary matters that are contained in the legislative regimes of member states and that need to be considered and

24 European Parliament resolution of 15 November 2011 with recommendations to the EC on insolvency proceedings in the context of EU company law (2011/2006(INI)) at recital $\mathrm{C}$ and available at <http://www.europarl.europa.eu/sides/getDoc.do?pubRef=-//EP//TEXT+TA+P7-TA-2011$0484+0+\mathrm{DOC}+\mathrm{XML}+\mathrm{V} 0 / / \mathrm{EN}>$.

25 Ibid, recitals $\mathrm{A}$ and $\mathrm{B}$.

26 Potential Economic Gains from Reforming Insolvency Law in Europe, 5 <http://www.weil.com/ /media/articles/2016/february/afme-weil-eu-insolvency-reform.pdf?la=en $>$ and now available at: <https://www.accountancyeurope.eu/finance-investment/fee-cmu-policy-update-2/>.

27 European Parliament (n 24), recital C.

28 EC (n 22), chapter 4.

29 Regulation (EU) 2015/848 of the European Parliament and of the Council of 20 May 2015 on insolvency proceedings (recast), Official Journal of the European Union, L141/19, 5 June 2015. For a recent discussion of the recast regulation, see M Weiss, 'Bridge over Troubled Water: The Revised Insolvency Regulation' (2015) 24 International Insolvency Review 192; G McCormack, 'Something Old, Something New: Recasting the European Insolvency Regulation’ (2016) 79 Modern Law Review 121.

30 Slot (n 3) 382.

31 D Mindel and S Harris, 'The Pursuit of Harmony Can Easily Lead to Discord - Why Local Insolvency Laws Are Best Developed Locally' (Ernst and Young April 2015) 3. 
addressed in the formulation of any harmonised scheme, as well as to ascertain the problems that these matters may cause in the construction of a legislative scheme. There may be other matters that lie outside the regimes of member states at the moment that need to be considered, but due to constraints of space that issue will not be broached here. The subject of the paper is a critical issue, for it is all well and good to say that there should be harmonisation, but how that is done and what is included in any harmonised scheme is another matter. Clearly, it is not going to be an easy task to draft provisions which provide a system that is fair, effective, workable and respected in all parts of the $\mathrm{EU}$, as the avoidance rules that exist in most member states have developed over many years and have done so in order to address particular concerns and issues that have arisen.

Nor is it within the scope of the paper to consider the benefits and drawbacks of harmonisation or to specify how avoidance rules should be formulated. ${ }^{32}$ Rather, on the basis that harmonisation were to occur, the paper proceeds to examine what has to be taken into account as far as the technical aspects of avoidance rules are concerned, and with reference to what is the existing position in the various member states. ${ }^{33}$ It must be added that this article does not seek to provide a template for harmonised rules, let alone suggest what a scheme might look like and how it would operate. The paper is situated further back than that in the development of a scheme. It aims to analyse the primary issues that need to be considered in the formulation of rules and to make a case for certain approaches. Because of the number of factors that warrant consideration and publishing limits, it is not possible to analyse them individually in as much depth as they deserve. This is something that will have to be done at the point of formulating a harmonised avoidance regime. While giving appropriate examples of avoidance rules applying across the EU, the paper does not seek to discuss the avoidance rules applying in member states in any detail. The recent report for the EC encompassing a study into substantive insolvency law in the EU does that to a degree. ${ }^{34}$

The article is structured as follows. First, it explains the nature of avoidance rules and the policy that appears to underpin them. Second, it discusses the kinds of antecedent transactions that are often subject to avoidance rules. In the third and principal part of the article, there is an analysis of the main factors that seemingly need to be considered either before the drafting of a scheme commences or in the process of drafting such a scheme, with these factors being based on the avoidance rules that presently exist around the EU. Finally, there are some concluding remarks.

For ease of exposition and because more transactional avoidance tends to occur in corporate insolvencies, I will assume that the debtor is a company, but there will be need, of course, for avoidance rules to apply to individual debtors. Whether they are broadly the same or different is something that will have to be considered. The article refers to the person who initiates avoidance actions as the claimant, and the person or entity against whom action is taken is referred to generally as the defendant or the beneficiary of a transaction. The claimant will, most often, be the person who has been appointed to administer the debtor's affairs pursuant to insolvency proceedings. For the purposes of this article this person will be referred to as an insolvency practitioner, which is the term used in the recast version of the EIR. ${ }^{35}$

32 For a discussion, see A Keay, 'The Harmonization of the Avoidance Rules in European Union Insolvencies' (2017) 66 International and Comparative Law Quarterly 79.

33 For a consideration of the issues surrounding harmonisation of avoidance rules, see ibid.

34 EC (n 22) chapter 4.

35 Art 2(5). Previously the person was referred to as the liquidator. 


\section{Avoidance rules}

Historically, avoidance rules go back to Roman times where there were up to four legal processes that could be used to recover property for the estate of a debtor from other parties, with the most well-known action being the actio pauliana. ${ }^{36}$ The main features of this action have survived to the present day. ${ }^{37}$ Over the years European jurisdictions developed their rules on avoidance in different ways and these rules include divergent elements and place emphasis on multifarious approaches, as we see later in the article. This is due to many factors, not least being the sources of law of a country, its history, culture and the kind of legal system that was fostered. Nevertheless, we find today that, while legal systems in the various jurisdictions of the EU differ, the solutions which these systems provide for in relation to antecedent transactions involving the loss of assets of insolvents have many commonalities, ${ }^{38}$ which does assist, to some degree, in formulating a harmonised regime.

One of the primary duties of an insolvency practitioner appointed to administer many types of insolvency regimes, and liquidation in particular, is to investigate the affairs of the insolvent that is subject to the relevant insolvency proceedings. An important aspect of this is to determine if there were any transactions entered into by the insolvent before the advent of insolvency proceedings to see if any of them are suspect and can be attacked because they are detrimental to creditors. Avoidance rules obviously are retrospective in effect and permit the setting-aside of transactions that were, at the time they were entered into, generally, valid and not vulnerable to challenge under the general law of the relevant jurisdiction.

No standard theory has really developed in Europe as to the reason for the existence of avoidance provisions, but there are clear policies that underpin them. First, the property of an insolvent is to be distributed fairly and rateably among its creditors, ${ }^{39}$ subject to provisions contained in the statutory scheme. ${ }^{40}$ Avoidance actions might be seen as promoting collectivism and fairness among creditors, and the underlying purpose of avoidance provisions is usually seen as being to ensure that there is fairness. ${ }^{41}$ Nevertheless, fairness does not translate into absolute equality between creditors as legislation in all member states includes provisions embedding the right of priority to certain groups of creditors. A prime example is employees of the insolvent who are usually granted some form of priority in all member states.

Avoidance rules are enacted so as to protect the general body of creditors from the unfair diminution of the insolvent's assets which can be a consequence of a debtor

36 The other actions were: interdictum fraudatorium; in factum; in integrum restitutio: H Roby, Private Roman Law (Cambridge University Press 1902) 273.

37 Seagon v Deko Marty Belgium NV (Case C-339/07) [2009] BCC 347, [26].

38 Ibid [26].

39 V Finch, 'Directors' Duties: Insolvency and the Unsecured Creditor' in A Clarke (ed), Current Issues in Insolvency Law (Stevens 1991), 87; E Warren, 'Bankruptcy Policymaking in an Imperfect World', (1993) 92 Michigan Law Review 336, 353; J McCoid, 'Bankruptcy Preferences and Efficiency: An Expression of Doubt' (1981) 67 Vancouver Law Review 249, 260; A Keay, 'In Pursuit of the Rationale behind the Avoidance of Preliquidation 'Transactions' (1996) 18 Sydney Law Review 56.

40 The most prevalent exception that is found is that the employees of the insolvent are entitled to be paid a part or all of outstanding wages owed to them before other creditors are paid.

41 McCoid (n 39) 271; T Ward and J Shulman, 'In Defence of the Bankruptcy Code: Radical Integration of the Preference Rules Affecting Commercial Financing' (1983) 61 Washington University Law Quarterly 1, 16. Recital 63 of the recast EIR provides that equal treatment of creditors is an important element of the Regulation. 
giving an advantage to someone at some point before the opening of insolvency proceedings, and, therefore, there is a distortion in the distribution of the property of the insolvent according to the statutory scheme. Allowing for avoidance is aimed at preventing the unjustified enrichment of one individual to the detriment of all creditors. The provisions seek to address two possible situations. First, insolvents may transfer some of their assets, prior to entry into insolvency proceedings, at below market value, or purchase assets at above market value, in order to benefit some third party, often an associate or connected party; this is action that might be characterised as debtor misbehaviour. ${ }^{42}$ Second, a debtor may discriminate in the payment of creditors and satisfy one creditor while ignoring others, which ends up being detrimental to the general body of creditors. ${ }^{43}$ These situations often involve the debtor benefiting people who are associated with the debtor. Where a debtor benefits a creditor who is not associated with the debtor, it often is the consequence of pressure brought to bear by the creditor when the creditor becomes aware of the fact that the debtor is in financial distress and might in fact be insolvent.

A second policy, which arguably has only risen to prominence in the past 25 years, is that avoidance provisions exist in order to stop the dismemberment of the insolvent's estate, ${ }^{44}$ which is something that can happen when an insolvent enters into transactions prior to insolvency proceedings being opened. The concern is that a reduction of funds and assets might seriously reduce the chances of the insolvent being able to continue to carry on business effectively or at all, and reduces the possibility of the insolvent being able to be restructured. ${ }^{45}$ Rules providing for the avoidance of certain antecedent transactions can, arguably, be a factor in protecting the insolvent's estate and, ultimately, the creditors as a general body, as well as exacerbating the debtor's insolvency problems. ${ }^{46}$ It would seem that this policy has become of greater importance in recent years as the restructuring of companies has been increasingly regarded as a critical issue in many nations within the EU and is something on which the EC has itself placed emphasis. ${ }^{47}$ Nevertheless, the existence of avoidance rules is unlikely to prevent dismemberment for the most part as they only apply expost and creditors, in particular, are likely to put in train processes that will enable them to get paid when a debtor is insolvent or nearing insolvency and then hope that a subsequently appointed insolvency practitioner will decide not to take legal proceedings in order to avoid relevant transactions. On many occasions creditors, for instance, will not know whether a company will be able to be restructured successfully, so they are likely to grab what they can when they can. Unless the continuation of the business of the insolvent is likely to benefit them in some substantial way, such as the fact that the company is a critical customer, creditors may be unconcerned that their receipt of full or partial payment might contribute to the eventual demise of the debtor.

42 A Keay, Avoidance Provisions in Insolvency (Law Book Co 1997), 35.

43 'Harmonisation of Insolvency Law at EU Level: Avoidance Actions and Rules on Contracts' (Briefing Note 2011) 11

44 J Westbrook, 'Two Thoughts about Insider Preferences' (1991) 76 Minnesota Law Review 73, 77; Keay (n 39); R Parry, 'The Rationale of the Transaction Avoidance Provisions of the Insolvency Act 1986' in R Parry, J Ayliffe and S Shivji (eds), Transaction Avoidance in Insolvencies (2nd edn, Oxford University Press 2011) 23, disagrees that as far as UK law is concerned that this is a relevant policy.

45 'Harmonisation of Insolvency Law at EU Level' ( $\mathrm{n} 43) 11$.

46 L Pineiro, 'Towards the Reform of the European Insolvency Regulation: Codification rather than Modification' (2014) 2 Nederland Internationaal Privaatrecht 207, 212.

47 EC, 'Recommendation of 12.3.2014 on a New Approach to Business Failure and Insolvency' C (2014) 1500 https://publications.europa.eu/en/publication-detail/-/publication/3d2631f9-ab55-11e3-86f9$01 \mathrm{aa} 75 \mathrm{ed} 71 \mathrm{a} 1 /$ language-en>. 
A third policy might underlie the avoidance rules. That is, they are designed to deter parties from entering into transactions with insolvents that could be avoided. If such a policy exists, it is highly questionable as to whether it works, given the present state of avoidance rules around the EU and the fact that many parties will take the benefit of such transactions because the company might be saved from entering insolvency proceedings, and, even if it does enter such proceedings, the insolvency practitioner might take the decision not to commence avoidance provisions for any one of a number of reasons, such as lack of funding or evidence. Those benefiting from a transaction with an insolvent might reason that, even if avoidance proceedings are commenced, there might be a deal to be done that will settle the proceedings. Also, even if an avoidance action is pursued and is successful, there will be no penalty imposed on the defendant other than the fact that the benefit of the transaction is lost. Moreover, if a creditor is ordered to return a benefit that is regarded as a preference, the creditor is not prohibited from claiming in the insolvent estate for what is owed. The upshot is that there is little reason why a party would not enter into a transaction if a benefit could be obtained.

The successful end result of a transactional avoidance action will be an enhancement of the corpus of property that is available to the creditors as a whole, and, it is hoped, it will provide a better dividend for creditors.

Important issues in relation to avoidance are predictability and certainty, and these are two factors that might lead to a decision to harmonise avoidance rules. All parties, whether it be a creditor providing credit in the sale of goods, a bank lending money or the insolvency practitioner in insolvency proceedings, need to know the effect of entering into transactions and when there can be interference in the normal processes of commerce.

\section{Antecedent transactions}

The regimes that member states provide for the avoidance of transactions differ in structure. $^{48}$ For example, some regimes consist of only one broad rule, such as transactions that cause detriment to the creditors are to be set aside, whereas other regimes are much longer and provide greater detail. Although some transactions entered into in the time prior to the advent of insolvency proceedings are generally set aside in a vast majority of member states, and notwithstanding that it has been said that national legal systems do not fundamentally differ with regard to the categories of contestable transactions, ${ }^{49}$ the laws around the EU do provide for the avoidance of various and different types of transactions. It is not possible in this article to identify and discuss the different transactions that are detrimental to creditors. As legal systems often group different types of transactions into categories, ${ }^{50}$ we will focus on the categories. The reason for doing so is that it is highly likely that member states will not accept a harmonised system that does not provide for the avoidance of these categories, and so, for the purposes of this paper, it is conceded that these categories will have to be addressed by a harmonised scheme. The two most prevalent of the categories are, first, transactions that constitute preferences and benefit one or more creditors in relation to the general body of creditors, and, second, transactions which have the effect that the

48 EC (n 22) Chapter 4.

49 European Parliament (n 18) 7.

50 R J de Weijs, 'Towards an Objective European Rule on Transaction Avoidance in Insolvencies' (2011) 20 International Insolvency Review 219, 220. 
insolvent loses out and hence so do the insolvent's creditors in subsequent insolvency proceedings because some third party has benefited from, or as a result of, transactions. ${ }^{51}$

The recent report undertaken for the EC on substantive insolvency law in the EU determined that all EU member states include in their avoidance rules some kind of preference provision, with many similarities between the rules in various states. ${ }^{52}$ Preferences involve the debtor (who subsequently enters insolvency proceedings) giving some benefit, perhaps payment of a debt owed or the creation of security in favour of one of the debtor's existing creditors, and this is to the detriment of the other creditors who do not get paid or receive any security in relation to the debts owed to them. The creditors suffer detriment in that priority creditors such as employees may not get paid what they are owed, and/or non-priority creditors, who will have to share pari passu with one another, ${ }^{53}$ will receive nothing or less from what is left in the insolvent's estate because a transaction was entered into. In several member states special rules apply to payments that are made before the date that payment is due or where payment is made in an irregular manner. ${ }^{54}$ The beneficiaries of such payments are seen as being less worthy of protection and the payment more reprehensible. In other states no distinction is made between payments that are due and owing and those that are not. ${ }^{55}$ Any consideration of a harmonised regime will have to decide whether to make any distinction between those transactions involving payments made when they were due to be paid by the debtor and those transactions that involved payments being made before the debt was due or were made in an irregular manner.

A second category of transaction is the transaction at an undervalue. This involves a debtor providing some benefit to a third party, usually someone associated with the debtor, that enriches the third party to the detriment of the debtor and eventually, if the debtor enters insolvency proceedings, the debtor's creditors. An example would be where a company sells an asset valued at $€ 100,000$ to the spouse of one of the company's directors for $€ 50,000$. In this example the debtor's estate has lost $€ 50,000$. A gift of its property by a debtor is another clear example of a transaction at an undervalue. ${ }^{56}$ The abovementioned EC-commissioned study on substantive insolvency found that all member states, except for Cyprus, have some form of transaction at an undervalue avoidance rule. ${ }^{57}$

All but nine member states have some avoidance rule(s) that applies where debtors have sought to put their assets beyond the reach of their creditors. ${ }^{58}$ This is sometimes known as a transaction intended to defraud creditors and sometimes as a fraudulent conveyance. ${ }^{59}$ With these kinds of rules for avoidance, either or both the debtor and the recipient of the benefit of the transaction must be proved to have intended to defraud creditors of the debtor. These kinds of transactions can be placed in the second category as the relevant transaction involves the debtor not receiving the amount of value that it should from the transaction.

51 See the discussion in Keay (n 39) 59-61.

52 EC (n 22) 147-2.

53 That is equally and rateably.

54 These are known as incongruent payments in Germany (German Insolvency Code (Insolvenzordnung) 1994, s 132) and voluntary payments in the Netherlands: de Weijs (n 50) 231.

55 For instance, see the UK and Ireland.

56 For example, as in Germany: s 134 of the German Insolvency Code 1994.

57 EC (n 22) 154-6.

58 Ibid 163.

59 See Art 3:45 of the Dutch Civil Code. 
A significant number of member states, with only five exceptions, include some kind of avoidance rule that invalidates the provision of security in favour of a hitherto unsecured creditor. ${ }^{60}$ For example, $\mathrm{X}$, an unsecured creditor of Y Ltd who is owed a substantial amount, agrees to refrain from taking legal proceedings against $\mathrm{Y}$ Ltd if the company agrees to give $\mathrm{X}$ security for the existing credit. This involves both X's debt being converted from being unsecured to secured, and it leaves the company in no better position financially than it was before granting the security. More importantly, creditors of Y Ltd will, if the company enters insolvency proceedings, be worse off, as the creditor who is now secured will get more from the estate of Y Ltd than the unsecured creditors. Two instances of the invalidation of transactions providing security bear a mention. First, in the UK floating charges may be invalidated when they are granted by companies that are on their last legs 61 and the creation of which will be to the detriment of the unsecured creditors. Second, in Germany ${ }^{62}$ any security that is created by a debtor within the three months before an insolvency filing and at a time when the debtor is in a position of illiquidity can be avoided if, at the time of the granting of security, the creditor who became secured as a result of the creation of the security knew of the illiquidity. ${ }^{63}$ The voiding of security is really allied to preferences as the general thrust behind the former is to prevent a creditor gaining a preference over other creditors by taking security which will give it, in most states, priority over other creditors. Security and secured interests are treated differently across the EU, ${ }^{64}$ and this can lead to problems where an insolvent's property is subject to security that was created in a different member state of the EU to the one in which insolvency proceedings have been opened under the EIR. ${ }^{65}$ This is exacerbated by the fact that there is no exhaustive definition of security (rights in rem) in the EIR. ${ }^{66}$

How the rules are drafted and whether the avoidance of other types of transactions should be catered for is a matter for a detailed study of the policy behind avoidance, the existing rules in member states and the breadth of such rules. The latter two issues will involve some consideration of important issues that hitherto have been taken into account in the formulation of existing national legislation.

\section{Critical factors in a harmonised scheme}

If harmonisation is to be implemented, there are a number of factors that have to be examined. In some cases it is inevitable that there will have to be a resolution of issues, precipitated by divergence of approach in relation to how these factors found in the legislation of member states are addressed, if at all. One cannot put a gloss on the fact that in some areas there are almost opposing positions taken by different states. The existence of some of the elements making up an avoidance rule can be a highly

$60 \mathrm{EC}(\mathrm{n} 22), 163$.

61 Insolvency Act 1986, s 245 (references to the Insolvency Act are to the British Insolvency Act 1986). For a discussion, see A Keay, McPherson and Keay's Law of Company Liquidation (4th edn, Sweet \& Maxwell 2017) 72837.

62 Other member states have similar provisions. For example, see Italy: Clifford Chance, European Insolvency Procedures (Clifford Chance LLP 2012) 34.

63 German Insolvency Code 1994, s 132; Clifford Chance (n 62) 49.

64 Miguel Virgos and Etienne Schmit, Report on the Convention of Insolvency Proceedings (the Virgos-Schmit Report) (Council of the EU, 3 May 1996) para 100.

65 See, A Keay, 'Security Rights, the European Insolvency Regulation and Concerns about the Non-application of Avoidance Rules' (2016) 41 European Law Review 72.

66 G McCormack, Secured Credit and the Harmonisation of Law (Edward Elgar 2011) 54. 
controversial matter. ${ }^{67}$ One reason that the rules that apply in each state can be so important is that they will affect how the assets of debtors will be distributed and they 'reflect the different policy goals pursued by governments and policy makers'. ${ }^{68}$

Before formulating the rules for avoidance it is necessary for there to be an articulation of the objectives of the inclusion of such rules in insolvency legislation as the objectives will determine what the rules should be. Consensus has to be reached on the fundamental principles that should be implemented in the laying down of avoidance rules. This is important for coherence. The rules must be consistent internally, and they must be consistent with one another.

It has been said that, besides coherence, the following principles must be considered: clarity and precision; thrift; ${ }^{69}$ comprehensiveness; ${ }^{70}$ and the optimal realisation of legal values. ${ }^{71}$ After coherence, it has been suggested that the most important principle to be considered in the construction of a legislative scheme is the optimal realisation of (legal) values, because 'a system of law that leads to the reasonable weighing of values can be considered to be well organised'. ${ }^{72}$

What is clearly to be at the heart of any scheme is that a transaction will only be able to be impugned successfully if it does in fact cause a detriment to the creditors as a whole. This must be the basis behind avoidance, and so, if a transaction occurs on the eve of a company's liquidation because of insolvency but involves the debtor receiving fair value from another for what it has purchased or sold, there is no ground for avoidance as neither the debtor company nor its creditors have suffered a loss.

Now we turn to consider some of the most significant issues that are included in avoidance rules around the EU and which will probably have to be considered in any harmonisation process. The factors identified have been gleaned from the legislation of member states and the recent report prepared for the EC on substantive insolvency law in the EU, ${ }^{73}$ with some consideration of the academic and practitioner literature.

\subsection{ESTABLISHING INSOLVENCY}

While it might be expressed in different words, the vast majority of EU jurisdictions provide that transactions can only be set aside if the debtor was insolvent at the time of the making of the transactions sought to be avoided. ${ }^{74}$ The pervasive use of an insolvency condition for avoidance satisfies the need to consider it here, given the approach articulated at the beginning of this part of the article. Nevertheless, there are good reasons why it should be a condition. For instance, arguably, transactions should not be able to be challenged prior to insolvency as it is only at that point that the company is clearly in financial trouble and it is likely that those dealing with it would only have become aware of these troubles when insolvency can be established.

67 F Mucciarelli, 'Not Just Efficiency: Insolvency Law in the EU and its Political Dimension' (2013) 14 European Business Organization Law Review 175.

68 Ibid.

69 This refers to the requirement that a system should not, without good reason, be complex due to 'redundant and overly complicated constructions': Haentjens (n 5) 15.

70 This requires a system to cover all case law and legislation: ibid.

71 P W Brouwer, 'Systematisering van recht' in P W Brouwer et al eds, Drie Dimensies Van Recht: Rechtstheorie, Rechtsgeleerdheid, Rechtspraktijk (Boom Juridische uitgevers 1999) 219-37, 232, and referred to in Haentjens (n 5) 15.

72 Haentjens (n 5).

73 EC (n 22).

74 Ibid 186. For instance, in Germany: see s 132 of the German Insolvency Code 1994. 
For a harmonised scheme, it would be necessary to establish a definition of insolvency, for a failure to do so would mean that the kind of certainty that parties crave would not be achieved. Notwithstanding the different terminology used in member states, there is closeness of approach in relation to this factor. For instance, Germany, Austria, Croatia and Bulgaria refer to a debtor being illiquid or over-indebted and in a number of states, including Belgium ${ }^{75}$ and Luxembourg, ${ }^{76}$ avoidance can only occur where the transaction was entered into when the company ceased paying debts or had suspended payments. Being illiquid in Germany involves a debtor being unable to meet its mature obligations to pay ${ }^{77}$ and accords with the concept of cash-flow insolvency which is used in the UK and Ireland. The concept of the cessation of the payment of debts also accords with cash-flow insolvency. The explanation of insolvency in some member states is more precise. In Slovakia, for example, insolvency means that a debtor is unable to pay at least two debt obligations to more than one creditor after they have been due for 30 days. ${ }^{78}$ But, then again, in some other member states insolvency is not as precise. For instance, in the Italian legislation it is said that insolvency occurs with the failure to fulfil obligations or by other external factors that demonstrate the debtor's inability to regularly satisfy its obligations. ${ }^{79}$

The UK law provides that avoidance rules only apply where the debtor was unable to pay its debts at the time of the impugned transaction, and this can mean a number of things, but primarily it means that the debtor cannot pay its debts as they fall due (cashflow insolvency), or the debtor's liabilities are greater than its assets (balance-sheet insolvency). ${ }^{80}$ Over-indebtedness in Germany means that the debtor's assets no longer cover existing obligations to pay ${ }^{81}$ and is consistent with the concept of balance-sheet insolvency that applies in the UK and Ireland. ${ }^{82}$ It is likely that a statement about inability to pay debts in a harmonised regime would not be able to be extensive, and it will rely upon subsequent case law to determine the finer points of the meaning of insolvency. This does leave open the possibility for divergence, but it would be a matter for the Court of Justice of the European Union (CJEU) to ensure that the case law develops consistently as it has in other matters that have been difficult elements of the EIR. ${ }^{83}$

\subsection{SubjeCtive V OBJECTIVE}

One important matter that is provided for in avoidance provisions, and it often tends to be a highly controversial issue, is whether elements that have to be proved in order for the avoidance of a transaction are subjective or objective. If avoidance can occur when either certain facts and conditions are merely established, then the test provided for is objective, but, if avoidance will only be ordered if it can be proved that the debtor or the person who received a benefit from the debtor had some belief or intention, then that is subjective. Subjective tests are concerned with the state of mind of one or more parties

75 Belgian Bankruptcy Act 1997, Art 9.

76 Law on Commercial Companies 1915, Art 440.

77 German Insolvency Code 1994, s 17(2).

78 EC (n 22), 185.

79 Bankruptcy Law, Art 5.

80 Ss $123(1)(e), 123(2)$

81 German Insolvency Code 1994, s $19(2)$.

82 For further consideration, see EC (n 22) para 5.2.

83 Most prominent has been the CJEU's efforts in relation to determining the meaning of 'the centre of main interests'. See, Re Eurofood IFSC Ltd C-341/04; [2006] Ch 508; [2006] BCC 397; EC Interedil Srl v Fallimento Interedil Srl C-396/09; [2012] BCC 851; [2011] BPIR 1639. 
while objective tests are concerned with objective facts. An example of a test that is objective is providing that a transaction must fall within a certain time period. This matter can be established by events and accounts and there is no need to consider the beliefs or intentions of any parties. An example of a subjective test is found in UK law where it provides that a court order avoiding a preference will only be permitted if the insolvent is proved to have been influenced in deciding to give the preference by a desire to put the beneficiary of the preference in a better position. ${ }^{84}$ Many jurisdictions, such as the UK, have a mixture of objective and subjective tests in their array of avoidance rules, but the Netherlands only employs subjective tests. ${ }^{85}$

Clearly, both subjective and objective approaches have their shortcomings. It is not possible to discuss these in depth, but the leading shortcomings for subjective tests are as follows. First, it is frequently demanding on insolvency practitioners in many cases to be required to establish that a subjective test is satisfied. It is often not easy to prove the intention of a person, and even more difficult to establish the intention of a corporate debtor. Second, ascertaining whether a subjective test has been satisfied or not in an avoidance action is time-consuming; it can be a difficult issue for a court to deal with and the outcome of such proceedings is often uncertain, ${ }^{86}$ or at least more uncertain than where there is no subjective test involved. The leading shortcomings of objective tests are: an objective test may precipitate uncertainty in that anyone dealing with a company cannot be sure that the transaction will not be avoided at some later point even if he or she did not know of the company's financial problems or the company had no intention of favouring the beneficiary of the transaction; and, if the objective facts can be proved, then the beneficiary of the transaction is liable when he or she might not have been at fault. ${ }^{87}$ This seems to be unfair, at least in some circumstances.

Bearing in mind that the general aim of the avoidance rules is to protect the collective scheme of insolvency and that the creditors must have suffered a detriment from a transaction, ${ }^{88}$ it makes more sense to provide, on the whole, for objective rules. To offset the harshness of such an approach defences could be provided for to enable a defendant/beneficiary to extricate himself or herself from liability if certain things can be established.

If it is felt that a subjective test has to operate, then what has to be decided is to which party or parties is the test to be applied. Usually, it is applied to either the debtor or the direct beneficiary of the impugned transaction. It could be applied to both and require that the test in relation to both parties had to be satisfied for an avoidance order, but that is likely to make it exceedingly difficult for insolvency practitioners to establish a case and get an order. There are different approaches across the EU as to whether the debtor or beneficiary's state of mind is included in the avoidance rule. For instance, German law provides $^{89}$ that, in determining whether or not a preference can be avoided, one has to consider the mind of the creditor/beneficiary of the preferential transfer, whereas in England and Wales it is the insolvent debtor's intention, and not the creditor's, that is one

84 Insolvency Act 1986, s 239(4).

85 R Vriesendorp and F van Koppen, 'Transactional Avoidance in the Netherlands' (2000) 9 International Insolvency Review 47, 51-4.

87 Ibid 223.

88 M Bridge, 'Collectivity, Management of Estates and Pari Passu in Winding up' in J Armour and H Bennett (eds), Vulnerable Transactions in Corporate Insolvency (Hart 2003) 18.

89 German Insolvency Code 1994, s 132. 
of the critical issues in being able to establish that a preference was given. ${ }^{90}$ It is submitted that, if there is to be a subjective test employed, and it might be more appropriate for some rules, it would seem more sensible to make the subjectivity to be that of the beneficiary/creditor and not that of the debtor. ${ }^{91}$ It does not seem fair that, if a beneficiary is blameless, as far as wanting a transaction to be detrimental to creditors of the debtor, he or she suffers a detriment, especially if the transaction is avoided because of the desire or knowledge of the debtor. There is a good argument for saying that it is just and reasonable to require some form of subjective test where the relevant avoidance rule seeks to allow the challenging of transactions that have been entered into in an attempt to defraud creditors. The allegation of fraud is a severe one and arguably requires clear proof of subjective intent. However, if one were to make the test dependent on the beneficiary's state of mind alone then it would be necessary to include a presumption (an issue that is discussed shortly) in relation to beneficiaries associated with the debtor that they would be presumed to have had the requisite state of mind for avoidance, or else, in rules such as transactions at an undervalue, debtors and associated parties might be able to conspire to ensure that the latter did not have the state of mind generally required.

If objective tests are to be implemented then there must be a time constraint placed on the right to avoid, or else it will create a substantial amount of uncertainty. ${ }^{92}$ For preference claims, the Americans have a 90-day period prior to the opening of insolvency proceedings in which all transfers by the debtor to a creditor can be set aside, but there is no defence at all to a preference claim provided that all of the conditions of a preference can be satisfied. While in Australia the period in which a preference can be said to have been given is six months, a fairly standard period in EU jurisdictions. In both the US and Australia those creditors who receive preferences within the period mentioned are able to invoke a defence. The next issue is whether a (and if so what) defence is to be made available to a beneficiary of a transaction that is entered into during the period in which a transaction might be set aside. A defence might involve some subjective element and thereby rectify the balance that might be thought to be prejudicial for a beneficiary who would be able to pass a subjective test. For example, a beneficiary's defence might be framed to permit the beneficiary to retain a benefit if he or she did not know that the debtor was insolvent at the time of the transaction. ${ }^{93}$ As mentioned already, the Australians do provide a defence to their objective test for preferences. In Australia a court is not to make an order materially prejudicing a right or interest of a person (the beneficiary of the transaction made with the debtor) if all of the following three conditions can be fulfilled: the person became a party to the transaction in good faith and at the time when the person became such a party the person had no reasonable grounds for suspecting that the company was insolvent at that time or would become insolvent; a reasonable person in the person's circumstances would have had no such grounds for so suspecting; the person has provided valuable consideration under the transaction or had

90 Insolvency Act 1986, s 239(5). But not in Scotland. The issue of desire is not relevant in England and Wales where the creditor who received the benefit is a connected person.

91 de Weijs (n 20) 5.

92 de Weijs (n 50) 226.

93 Such an approach would lead us to something close to the German position, although the burden of proof in having a defence as mentioned in the text would place the burden of proof on the beneficiary, whereas in the German position the claimant has the burden of proving that the beneficiary knew that the debtor was illiquid: German Insolvency Code 1994, s 132. 
changed position in reliance on the transaction. ${ }^{94}$ The US legislation allows for a defence when a payment was made in the ordinary course of business. ${ }^{95}$

The drawback for beneficiaries of transactions wishing to defend an insolvency practitioner's claim is that, usually, they have the burden of proving their subjective state in order to satisfy the defence.

\subsection{PREsUMPTIONS}

Legislation in many member states specifies that some presumptions, most of which are rebuttable by the person against whom the avoidance action has been instituted, will be applied in certain circumstances. The existence of presumptions is an implicit acknowledgment by legislators that insolvency practitioners would find it exceedingly difficult to prove some conditions that are contained in avoidance rules if they were not helped by presumptions. It is recognition of the fact that an insolvency practitioner comes to an insolvent's estate with very limited knowledge about the debtor's affairs and he or she can only obtain a restricted amount of information, often because the directors and other officers fail to co-operate. Also it might be an acknowledgment that certain transactions are either potentially or inherently questionable and therefore it is warranted that presumptions are applied. An example is a transfer of property to a party related to the company, such as a director.

A presumption that is included in some legislation is that, where it has to be established that the defendant to the avoidance action knew or ought to have known of the debtor's insolvency when entering into the transaction with the debtor that is impugned, the defendant's knowledge is presumed. The defendant then has to rebut that presumption. In constructing harmonised avoidance rules it will be necessary to consider what matters should be presumed, to whom will the presumption apply and whether or not it can be rebutted, and, if so, how.

\subsection{WHO CAN TAKE ACTION?}

It is of course a critical matter that there is some provision somewhere that identifies the one who is entitled to take action for the avoidance of a transaction. As INSOL Europe noted in its report on harmonisation of EU law on insolvency, different positions exist in member states as to who is entitled to initiate proceedings. ${ }^{96}$ The candidates are the insolvency practitioner (perhaps needing court or creditor approval in some cases), a government official, a court supervisor and possibly a creditor. Certainly, the insolvency practitioner is the most frequent claimant in an avoidance action in and outside of the EU. A creditor might be only able to bring proceedings on some occasions after securing the approval of one of the following: the insolvency practitioner, the court or some other independent body. It would seem to be unwise to permit creditors to bring proceedings without obtaining permission as the institution of avoidance actions would ordinarily be part of the role of the insolvency practitioner, and a creditor should have to establish a

94 Corporations Act 2001, s 588FG(2).

95 Bankruptcy Reform Act, s 547. This defence has caused uncertainty and precipitated a considerable amount of litigation: M J Herbert, 'The Trustee versus the Trade Creditor: A Critique of Section 547(c)(1), (2) and (4) of the Bankruptcy Code' (1983) 17 University of Richmond Law Review 667, 679; E A Orelup, 'Avoidance of Preferential Transfers under the Bankruptcy Reform Act 1978' (1979) Iowa Law Review 209; L L Broome, 'Payments or Long Term Debt or Voidable Preference: The Impact of the 1984 Bankruptcy Amendments' (1987) 78 Duke Law Journal 78.

96 European Parliament (n 18) 20. 
good reason why he or she believes that proceedings should be instituted when the insolvency practitioner did not do so.

In a Note, titled 'Harmonisation of Insolvency Law at EU Level: Avoidance Actions and Rules on Contract,' the European Parliament's Policy Section felt that harmonisation in respect of this issue was going too far and trespassing on the national domain, ${ }^{97}$ and thus it was viewed to be a matter for nation states as to who might be entitled to bring proceedings. This seems to be understandable and, whoever is entitled to bring proceedings, he or she will be bound by the harmonised scheme.

\subsection{Value}

It is a critical aspect of provisions that allow for the challenging of transactions at an undervalue and, to an extent, transactions that defraud creditors that it be established that the insolvent debtor did not receive as much consideration in money terms from the transaction as the other party to it. Hence, how one provides for the valuation of the consideration is an important element. Luxembourg, ${ }^{98}$ Malta ${ }^{99}$ and the $\mathrm{UK}^{100}$ include in their provisions dealing with transactions at an undervalue that the insolvency practitioner is obliged to prove that what the debtor received was, in money terms, significantly less than what the debtor gave to the other party. No definition or guidance is provided in the legislation and determining whether there was significant undervalue is left squarely within the discretion of the court. Other jurisdictions include reference to value in broad terms. The Hungarian legislation provides that there is avoidance where there is conspicuous undervalue in bilateral transactions. ${ }^{101}$ This, like the provisions in Luxembourg et al, suffers from vagueness. Other member states do refer to the unevenness of consideration passing between the parties to a transaction. For instance, the Polish legislation refers to disproportionately low consideration being received by the debtor. ${ }^{102}$ The legislation of many member states does not refer to unevenness of value, but merely provides that a transaction is voidable where it is detrimental to the creditors. Unevenness of value would be an indicator of detriment. Possibly, merely stating that a transaction can be avoided if it is detrimental to the creditors is preferable to stating the kind of undervalue that there must be, for it is less vague than the latter approach.

\subsection{THE SUSPECT PERIOD}

For the most part avoidance provisions specify a period of time in which a transaction must have been entered into for it to be subject to successful challenge. This is to ensure a degree of certainty and to protect contract finality. ${ }^{103}$ Most member states provide a number of time zones for different avoidance rules, although Spain, because it effectively has only one avoidance rule, has one time period applicable to all transactions that might be avoidable. Different periods are specified for the avoidance of different transactions under the law of the various member states. The periods can be quite diverse, and a number of them might be used in any one jurisdiction's avoidance rules. The avoidance of security interests particularly provides an instance of divergence. For instance, Germany's s 130 of its 1994 Insolvency Code provides that security can be contested if

97 European Parliament (n 18) 15-16.

98 Commercial Code, Art 445.

99 Companies Act, Art 303(2)(a).

100 Insolvency Act 1986, s 238.

101 Ibid s 40(1)(b).

102 Insolvency Law, s 127(1).

103 de Weijs (n 50) 226. 
it was created within three months of the opening of insolvency proceedings if the debtor was illiquid at the time of the transaction and the creditor knew of the debtor's illiquid state. Yet, in the UK the time period for the invalidation of some floating charges is where the charge was entered into in the 12 months before the commencement of liquidation or administration, but this is extended to two years if the creditor in whose favour the charge is granted is a connected party. ${ }^{104}$

The longest suspect periods tend to be reserved for transactions that involve fraudulent intent on the part of the debtor. For instance, there is no time limit prescribed for transactions to defraud creditors in the UK. ${ }^{105}$ The provision of a long time zone does, as with presumptions, help insolvency practitioners who are seeking to avoid an antecedent transaction. Transactions at an undervalue are often next in the length of the suspect period. For instance, in Germany the time period is four years. The shortest suspect period tends to be applied to preferences. Several jurisdictions provide that only transactions entered into during the period of three months before the commencement of insolvency proceedings can be avoided, ${ }^{106}$ while a substantial number of other jurisdictions employ a period of six months. ${ }^{107}$ One justification for a shorter period for preferences compared with undervalue transactions is probably that the former do not reduce the net estate for distribution while the latter do.

\subsection{Calculating the SUSPECt PERIOD}

Where time periods are established, it is important to know from what point one goes back in time to ascertain whether transactions are able to be avoided. The point is usually the time when insolvency proceedings are opened. What opening means can be different in each member state, and that caused some problems in the application of the EIR before its recast. This is a matter that would need to be considered very carefully as potentially it could be of critical importance.

\subsection{ASSOCIATION BETWEEN THE INSOLVENT AND THE COUNTER-PARTY (CONNECTED PERSONS)}

Some avoidance laws might only apply where the insolvent and the person or company with whom it makes the transaction are connected in some way. Alternatively, avoidance rules might apply equally to parties connected and unconnected to the insolvent, but the time in which the rule applies might be somewhat different. For example in the UK a preferential transfer can only be challenged when it is entered into within six months before the commencement of insolvency proceedings, 108 whereas that period extends to two years where the recipient of the preference is connected to the insolvent. ${ }^{109}$ Furthermore, the existence of a connected party in a transaction might provide an insolvency practitioner with the benefit of a presumption in some respects. An example is where the beneficiary of the transaction has to be proved to have been aware of the debtor's insolvency when the transaction was entered into; this is presumed if the beneficiary is a connected person.

104 Insolvency Act 1986, s 245.

105 Ibid s 423.

106 Croatia, Denmark, Finland, Hungary (90 days) and Sweden.

107 See Belgium, Bulgaria, Cyprus, Ireland, Latvia, Malta, Poland and the UK.

108 Insolvency Act 1986, ss 240(1)(b) and 341(1(b).

109 Ibid ss 240(1)(a) and 341(1)(c). 
The reason why a longer suspect period is usually provided for where there is a connected party involved in a transaction is that a connected party might either directly or indirectly cause the business of the debtor to continue for a term before it enters insolvency proceedings so that any transaction entered into falls outside of the suspect period that is provided for in the avoidance rules. Also, a connected person could either influence the directors of the company in the decisions they make, particularly as to whether the company enters insolvency proceedings, or they can even manipulate company decisions.

At present, all member states make provision for connected persons save for France, ${ }^{110}$ Malta and Luxembourg. ${ }^{111}$

If special provision were made for transactions that involve connected persons, and one would assume that legislation would do so given the fact that nearly all EU states currently make such provision, it has to be decided who is to be included within the category of connected person. This is not easily resolved. Usually, the following are included: relatives of an individual insolvent; directors and shareholders of an insolvent company; companies in the same corporate group as an insolvent company; and relatives of directors. ${ }^{112}$ But the various member states provide different definitions of persons who are connected. The Netherlands is particularly broad and includes foster children of a director of the debtor company. ${ }^{113}$ Other states that provide a fairly comprehensive list of connected persons are Poland and Spain, ${ }^{114}$ while others provide for a limited provision. An example is Italy where only spouses are seen as associated persons.

\subsection{THE AVOIDANCE OF TRANSACTIONS PECULIAR TO ONE OR FEW JURISDICTIONS}

A major issue that has to be considered is what approach is to be taken in relation to the avoidance of transactions that might be provided for in only one or two jurisdictions. The relevant provisions are notable as there is nothing or little to which they can be compared and they owe their existence to considerations that are often special to the particular member state. What is likely is that a matter that is covered by an avoidance rule in one member state might be dealt with in another state by provisions in non-insolvency legislation. An example of a provision that is peculiar to one state is the UK's provision for the avoidance of extortionate loans. ${ }^{115}$ Such transactions, or at least similar transactions, might be avoidable under consumer legislation or other civil law provisions in other member states.

It is obviously not possible for a harmonised set of avoidance rules, unless they are going to be overly long and complicated, to be able to encompass all of the rules that are peculiar to one or even a few jurisdictions. If a scheme were to do this it would be too complex. Provisions that presently exist in member states could be considered and evaluated as to whether they might be broadened and included in harmonised rules. If not, then national governments might consider moving the provision into some other piece of national legislation. Another option would be to permit states to add local rules on to a harmonised set of rules, provided that they do not clash or overlap with the

110 But personal links between the parties might be taken into account in determining whether the party dealing with the debtor was aware of the debtor's insolvency.

111 EC (n 22) 142.

112 See, for instance, Insolvency Act 1986, ss 249 and 435.

113 Bankruptcy Act, Art 43.

114 EC (n 22) 163.

115 Insolvency Act 1986, s 244. 
former. The drawback with this latter option is that it would not foster certainty. It would also mean that practitioners would not be conversant with, potentially, many different rules across the EU, which is one concern that has been voiced about the present state of affairs. ${ }^{116}$

\subsection{ORDERS}

Obviously, on most occasions it is the order of a court with which an insolvency practitioner is most concerned. Even where an avoidance rule renders a transaction void automatically, as some rules do, a court order might be needed to support the voiding of the transaction. For example, an order might be needed to force a party to pay money or return property to the estate of the insolvent. What is actually ordered can be critical. What the EC must consider, if deciding to embark on harmonisation, is whether the rules formulated will include specific directions as to what orders might be made, or whether the nature of the orders are left entirely within the discretion of the court hearing the matter. There are advantages and disadvantages with either approach. The advantage of provisions that specify exactly what a court can order if the claimant makes out his or her case is that the claimant knows what he or she will get if the case is successful. The disadvantage with it is that, while a judge might find creative ways of providing what he or she thinks is just, the judge's hands are tied to a large degree. The advantage with providing courts with wide discretion is that it enables courts to tailor their orders to do justice to the case, which might even include providing some allowances for the defendant, such as where the defendant has improved property which he or she received from the debtor and which has to be returned to the insolvent through the insolvency practitioner appointed because of the voiding of the transaction.

\subsection{TIME BARS}

There is provision in the legislation of most, if not all, member states providing that, as far as most avoidance rules are concerned, proceedings in the courts for an order of avoidance or a related order must be commenced within a specified time period or else the right to bring proceedings is lost. The importance of time bars or limitation periods is exemplified by the decision of the CJEU in Lutz v Bauerle. ${ }^{117}$ In this case an insolvency practitioner of a German company against which insolvency proceedings had been commenced in Germany could not recover certain funds pursuant to a German avoidance rule that had been paid from the insolvent company's Austrian bank to the beneficiary in Austria. The reason was that under Austrian law, although not under German law, the time for bringing proceedings had elapsed. The CJEU said that the Austrian law took precedence because of Article 16 of the EIR. ${ }^{118}$

The limitation period varies in member states. It is two years in Poland, ${ }^{119}$ three years in Germany, the Netherlands and Italy, and in the UK it depends on the type of claim that is made and is either six or 12 years. ${ }^{120}$ The harmonisation of a period of time, which may involve a different period for each kind of avoidance rule, might conceivably not be a major obstacle to harmonisation. But the greater problem is that the point from which time runs differs across the EU. In Croatia, Germany and Italy it begins from the

116 European Commission (n 22) para 4.13 .

117 Case C-557/13, [2015] EUECJ C-557/13. The case is discussed in Keay (n 65).

118 Art 13 under the EIR as it applied at the time of the case. It is Art 16 under the recast EIR.

119 Although it is five years for actions that are classified as actio pauliana claims.

120 Limitation Act 1980, ss 8 and 9. 
point when the insolvency proceedings are opened. ${ }^{121}$ In the UK time runs from the date on which the cause of action accrued, which will normally be the date of the appointment of the insolvency practitioner. In other states, such as Poland and Portugal, it is from the date of the declaration of bankruptcy, and elsewhere it will begin from the time when the insolvency practitioner becomes aware of the relevant facts that indicate a transaction can be avoided. ${ }^{122}$ This is the case in Greece, for instance, where the insolvency practitioner has one year to bring the proceedings. ${ }^{123}$ Even if a common starting point were prescribed, such as the opening of insolvency proceedings, this is different in member states, and it is not always clear what is the opening of proceedings. ${ }^{124}$ Perhaps one possible solution is to nominate the appointment of an insolvency practitioner as the commencement of the time period and then provide a particular time running from that point.

Unfortunately, while the issue of time bars might be seen as procedural, it is something that cannot really be left to national states, because it can have, as Lutz v Bauerle $^{125}$ demonstrates, a major impact on whether avoidance rules are able to be enforced, and if each member state were to retain its own limitation period for avoidance rules it would defeat the need for certainty, one of the prime reasons behind harmonisation. It would make it more difficult for insolvency practitioners to know what time they have to work to, and a full knowledge of the limitations in 27 (excluding Denmark) states is unreasonable. Also, divergence on the actual periods could be seen as producing inequality and unfairness.

In weighing up the inclusion of a limitation period considerable thought would have to go into whether a period on the short side were proposed or whether a long period was appropriate. The danger with short limitation periods is that they places a significant burden on insolvency practitioners to determine whether transactions might be potentially avoidable, to seek legal advice, possibly obtain funding, and to gather the necessary evidence. Yet the advantage is that they serve to focus the mind of insolvency practitioners on such actions early on in their administration. The concern is that, if a period is unreasonably short, insolvency practitioners will either not be able to come to grips with the affairs of the insolvent sufficiently to decide whether avoidable transactions were entered into, and this is especially the case in relation to complex and large insolvencies, or they will simply not bother to address the issue of avoidance. Another danger is that proceedings might be commenced prematurely without the insolvency practitioner having really assessed the evidence. The consequence could be that the estate of the insolvent is vulnerable to the payment of costs to the person against whom proceedings were initiated and where the insolvency practitioner loses the case or withdraws. The benefit of long limitation periods is that it enables insolvency practitioners to be meticulous in their investigations and evidence gathering, but the potential drawback is that they can lead to procrastination or a lax approach in ascertaining whether transactions might be attacked or actually initiating the proceedings.

$121 \mathrm{EC}$ (n 22) 165.

122 Ibid.

123 Greek Insolvency Code, s 51.

124 This was made manifest in the celebrated case of Re Eurofood IFSC Ltd C-341/04; [2006] Ch 508; [2006] BCC 397.

125 Case C-557/13, [2015] EUECJ C-557/13 


\subsection{Transactions Relating to Restructuring}

When insolvent, a company might endeavour to engage in a restructuring process in order to try and save it from liquidation. The EU, in line with many of its member states, has gauged that it is important to permit a company to have reasonable chances of saving itself and reducing the losses of stakeholders, such as creditors and employees. This culminated in the EC's publication of a proposal in November 2016 for a Directive on preventive restructuring frameworks. ${ }^{126}$ In engaging in the process of restructuring a company is going to run up debts and may seek and obtain new financing with the aim of enabling it to continue to operate and possibly develop. If the company's attempt fails and it is placed in liquidation the avoidance rules will be considered by the insolvency practitioner. Consideration needs to be given to whether a harmonised regime of avoidance would entitle an insolvency practitioner to challenge transactions that were entered into during an attempt to rescue the company from its financial malaise.

In most member states, such as the Czech Republic, Estonia, Germany, Hungary, Lithuania, Luxembourg, Malta, the Netherlands, Slovakia and the UK, there is no special protection presently provided in relation to transactions involving the provision of new finance or the giving of credit on supply contracts, and avoidance rules will apply. ${ }^{127}$ So, a repayment of a loan during a restructuring process could be challenged as a preference in many member states provided that the payment fell within the conditions formulated for a preference. However, for the most part, any security that is granted in exchange for new financing, and in order to support restructuring, will usually be safe from attack. In this kind of case, the financier is giving something new to the company and the company is therefore benefiting; there is no ultimate detriment to the creditors. In some states the protection of security granted for new money is restricted somewhat. For instance, in France, new financing cannot be challenged if the lender supplied funds and it was in relation to a settlement that had been approved of by the court. ${ }^{128}$ The position in Romania ${ }^{129}$ and Slovenia ${ }^{130}$ is similar. In somewhat of a like manner, new financing cannot be challenged in Greece, where no new financing arrangements can be attacked subsequently provided that the new financing occurred during the execution of a restructuring plan. ${ }^{131}$ The proposed new Directive would protect new financing in that it would not be declared void or voidable as an act detrimental to creditors in the context of subsequent insolvency procedures except where the transactions had been engaged in fraudulently or in bad faith. ${ }^{132}$ There are incipient elements of such an approach in the rules that presently exist. For example, in Germany any transaction involving new financing is deemed not to have been entered into with the intention of harming creditors if it has been entered into pursuant to a serious effort to restructure. ${ }^{133}$

\footnotetext{
126 EC, 'Proposal for a Directive on Preventive Restructuring Frameworks, Second Chance and Measures to Increase the Efficiency of Restructuring', COM (2016) 723 final, 22 November 2016.

127 EC (n 22), 167.

128 Commercial Code L 631-8, 3.

129 Insolvency Law, Art 117.

130 Insolvency Act (ZFPPIPP) (Slovenia), Arts 44 and 273.

131 Insolvency Code, Art 45(c).

132 Proposed Art 16.1.

$133 \mathrm{EC}$ (n 22) 167.
} 


\section{Conclusion}

In his report for UNCITRAL in relation to the harmonisation of international trade law in 1966, Clive Schmitthof said that harmonisation would reduce conflicts and divergences, ${ }^{134}$ and arguably a harmonised avoidance law would also do this for European insolvencies, as well as overcoming many of the concerns that exist with the present state of the law. But the devil is not only in the detail; it is also in constructing a schema for harmonisation which involves identifying the leading issues that have to be considered. The point was made at the outset that this paper's purpose was not to endeavour to formulate harmonised rules. That will need to be done and will probably involve a fair degree of pragmatism, as obtaining a perfect scheme is impossible. What the paper has sought to do is to identify those factors that are important parts of avoidance rules across the EU and which will need to be considered by the EC in any attempt to harmonise. There will be some hard decisions to be made and not all of them might be seen as producing fairness. The problem is that we can try as hard as we are able, but not all aspects of insolvency law and practice will lead to fairness. The fact is that the advent of insolvency is such that some, if not all, will be disadvantaged to some extent. That is the nature of the insolvency event.

A recent study has found that all member states have avoidance rules in their insolvency legislation. ${ }^{135}$ The study has also found that all states, or at least a vast majority, have some form of avoidance rule in respect of four kinds of transactions: preferences, transactions at an undervalue, transactions defrauding creditors, and transactions granting security in certain circumstances. It is likely that any harmonised rules will cover these kinds of transactions. However, deciding on the kinds of transactions that will be legislated for is only part of the task. The way that the rules address the issues canvassed in this paper is a critical matter. The EC will have to decide which factors are dealt with in a harmonised scheme and what are left to individual states. The more that is left to individual nations to address, the more likely it is that there will be residual divergence that could attenuate some of the benefits of having a harmonised system of rules.

134 The Secretary-General, 'Report of the Secretary-General' delivered to the General Assembly, UN doc A/6396 \& Add 1 and Add 2 (23 September 1966), para 8, and referred to in Block-Lieb and Halliday (n 2) 493.

135 EC (n 22), Chapter 4. 